\section{American Expedition to Northern India}

SINce the beginning of March an American scientific expedition sent out by Yale University has, under the leadership of Dr. Hellmut de Terra, been doing geological and biological research in Northern India. Having visited the Salt Range, Dr. de Terra and Prof. G. E. Hutchinson, a biologist at Yale University, have proceeded to Kashmir, where they are making a geological and biological survey of the Kashmir valley. Ultimately they hope that this survey will make possible a clear understanding of the natural history of this southern Himalayan sector, from the pleistocene period to the present day. Another member of the party, Mr. G. E. Lewis, fellow in palæontology at Yale, has been collecting tertiary vertebrate fossils in the Siwalik formations of the Northern Punjab. On May 15 the expedition, accompanied by the surveying officer Khan Sahib Afraz Gul Khan, left Srinagar and started for the Eastern Karakorum, a field in which Dr. de Terra has already done geological work while accompanying Dr. Trinkler's Central Asia Expedition. Five months will be devoted to work in this region, which includes the still little known tract of land lying along the north-west Tibetan plateau. While the rest of the party will be busy with geographical and geological problems, Prof. Hutchinson plans to carry out limnological studies on the great Pangong and adjacent lakes which are among the highest lakes in the world.

IN reference to the work of this expedition in the Salt Range, Dr. L. L. Fermor, officiating director of the Geological Survey of India, writes from Calcutta to point out that a note in these columns (NATURE, Feb. 20, p. 275) on the plans of the expedition-which was based on an announcement issued by Science Service of Washington-"seems unjust to the Geological Survey", in suggesting that the Salt Range had not been examined systematically for palæontological evidence. Dr. Fermor directs attention to a number of contributions to the Memoirs of the Geological Survey and Palaeontologica Indica-on the geology by A. B. Wynne and Sir Edward Pascoe, and on the palæontology by R. Lyddeker, G. E. Pilgrim, W. Waagen, and others. In addition, Dr. Fermor states that the Range itself is now being surveyed in great detail by E. R. Gee.

\section{Early Man in Palestine}

Further information relating to the human skeletal remains found in the Mousterian strata of the Palestinian cave, Mugharet es-Sukhul (see Nature, May 14, p. 712), as given by Miss D. A. E. Garrod in a communication to the Times of June 11, indicates that the discovery is of even greater significance than at first appeared. Now that Mr. MacCown and his assistants have been able in part to remove the breccia in which two of the skeletons were embedded, it is becoming possible to appreciate the bearing of certain incompatibilities with the Neanderthal type, which Sir Arthur Keith had noted in the Galilee skull and other remains found in the Palestine caves in association with a Mousterian culture. These two skeletons are practically complete and lie as they were buried, one on its back, the other on its left side with legs flexed and heels drawn up towards the sacrum. Although the skull has the characteristic powerfully developed supraorbital ridges, the cranial vault is higher and the head somewhat rounder than in Neanderthal man; while viewed from behind, the greater breadth appears nearer the base and the sides are comparatively straighter, converging slightly towards the top of the head. Even more remarkable is the facial skeleton, which appears to exceed in prognathism the most prognathous of Neanderthal skulls, giving it an ape-like appearance. The lower jaw is as heavy and as squarely built as in Neanderthal man, yet it has a decided chin. The limb bones are massive, but longer than those of Neanderthal man; but it is evident that Palestine man walked with the Neanderthal slouch. In view of these facts, Sir Arthur Keith confirms the conclusion of the excavator that here we have a new race, or even a new species, of fossil man, for which Sir Arthur proposes the name Palceanthropus Palestinus.

\section{Tornadoes in the United States}

IN the Monthly Weather Review for last December there is a preliminary report on the frequency of tornadoes in the United States during 1931, on the number of deaths caused by them, and on the material damage. This report shows that in the past year tornadoes were notably scarce compared with other recent years, and did less damage than usual; also that, what is even more satisfactory, they caused less than half the number of deaths recorded in any of the previous fifteen years. Even so, the death roll, resulting from about ninety of these visitations, reached 34, of which no fewer than 14 occurred last December. The unit in which material damage is expressed is the sum of a thousand dollars, and in five months the total damage thus expressed ran into three figures; September was outstanding with 828,000 dollars' worth of damage caused by twelve or thirteen tornadoes. The figures for monthly frequency of occurrence of the storms show a characteristic early summer maximum, with a total of 32 storms in May and June, that is, of more than a third of the year's total. It may be noted that although the tornado and the commonest type of summer thunderstorm are probably both caused by local instability due to the juxtaposition of air masses of different temperature, of which the warmer generally carries a great quantity of water vapour, they must be regarded as in some way essentially different in their modes of origin.

\section{The Five-Year Plan in Russia}

A sERIES of economic studies of Russian production under the Five-Year Plan is being published by the Bureau of Research of the Russian Department of the University of Birmingham, under the editorship of Prof. S. Konovalov. No. 5 deals with the economic results for 1931, agricultural collectivisation, and oil production and export. The statistical presentment of the plan is of much interest. As regards agriculture, it is shown that while the 1913 output of

$$
\text { Noo. 3268, VoL. 129] }
$$


cereals was 81.6 million tons, the average output in 1927,1928 , and 1929 fell to 72.9 million tons, or a decrease of 10.7 per cent. This, however, was increased in 1930, under collective farming, to 87.4 million tons; but the hopes for 1931 of 97.9 million tons fell short by as much as 21.5 million, which, with an annual growth of population of $2 \cdot 36$ per cent, has meant a cessation of export. The shortage would appear to have been largely due to vain attempts to increase too rapidily the area under cereals, which led to badly propared soil, thin sowing, and delayed harvests. Less favourable weather was another cause. Novertheless, the sown area of cereal and other crops has been increased during the last yoar by more than seven per cent. An analysis of the output of large scale industry shows an increase in the last year of 2I.7 per cent, against the anticipated $44 \cdot 3$ per cent. At the same time, there are other negative results which are fully analysed in this report, such as the decrease in the productivity of labour, and the increase in cost of production and in prices.

\section{Antirabic Treatment in India}

That dread disease hydrophobia, caused by the bite of rabid animals, is of considerable importance in India, and 456 deaths were attributed to it in 1930 in the Madras Presidency. The report for 1930 of the Director, Major Iyengar, of the Pasteur Institute of Southern India, Coonoor, records that $54 \mathrm{I}$ patients were treated at the Institute, with 5 deaths, a mortality rato of 0.92 per cent. In addition, 4747 cases were treated at other centres in the Madras Presidency, with $\check{5}$ deaths. Semple's carbolised sheep vaccine was used throughout, the virus being in its 1Ij4th passage at the end of the year. Animals to the number of 229 , including one elephant, were also treated, with no death. Bites treated were inflicted by eleven species of animals, including man, panther, leopard, jackal, and fox.

\section{Investigation of the Atmosphere in the U.S.S.R.}

A scientific institute has recently been established in Moscow to carry on research on the circumstances of formation of eloud, fog and rainfall. The institute has branches in Leningrad, Odessa, Saratov, Teshkent, and Askhabad. The Leningrad branch of the institute is installing apparatus for investigating the effect on the atmosphere of high-tension currents, X-ray, ultraviolet rays and radioactive raciations. It is hoped to test the apparatus next simmer in experiments to be carried out in the drought regions of the U.S.S.R.

\section{Announcements}

AT a congregation held at Cambridge on June 11, the honorary degree of Sc.D. was conferred on Sir William Bragg, director of the Royal Institution.

Dr. Hentry S. Washingtos, the distinguished petrologist of the Geophysical Laboratory of the Carnegie Institution of Washington, has been elected an honorary member of the Mineralogical Society.

Prof. H. E. Armstrong will deliver the next Huxley Memorial Lecture at the Imperial College of

$$
\text { No. 3268, VoL. 129] }
$$

Science and Technology on May 4, 1933. Prof. Armstrong will speak on Huxley's educational creed and its outcome.

THE following committee has been appointed to inquire into the sterilisation of mental defectives : $\mathrm{Mr}$. L. G. Brock (chairman), Dr. Wilfrod Trotter, Dr. R. A. Fisher, Dr. A. F. Tredgold, Miss Ruth Darwin, Dr. E. W. Adams, Dr. R. H. Crowley, Dr. E. O. Lewis, with Mr. F. Chanter, of the Board of Control, as secretary. The terms of reference are: "To examine and report on the information already available regarding the hereditary transmission and other causes of montal disorder and deficiency ; to consider the value of steril. isation as a preventive measure, having regard to its physical, psychological, and social effects, and to the experience of legislation in other countries permitting it; and to suggest what further inquiries might usefully be undertaken in this connexion".

Thw reports of the destruction of a gaol at Mymensingh, in Bengal, on May 9 last, by a tornado, were probably ineorrect in attributing the damage to a tornado, for the 'nor'westers' are quite capable of doing all the damage described on this occasion and are particularly frequont in May. These squalls, associated with early summer thunderstorms in Northern India, can be very violent.

A swW catalogue (No. 549) of second-hand books and journals has just reached us from Francis Edwards, Ltd., 83 High Street, Marylebone, W.1. It comprises nearly 1700 works-many rare-dealing with folklore and anthropology.

Applications are invited for the following appoint. ments, on or bofore the dates mentioned :-A lecturer in the Chemistry Department of the Heriot-Watt College, Edinburgh-The Principal, Heriot-Watt Colloge, Edinburgh (June 20). A principal of the Walsall Technical College-The Director of Education, Education Offices, Council House, Walsall (June 25). A principal of the Chelmsford School of Art and Technology--The Director of Education, County Offices, Chelmsford (June 25). A lecturer in zoology (botany subsidiary) at the Chelsea Polytechnic-The Principal, Chelsea Polytechnic, Manresa Road, S.W.3 (June 30). A lecturer in the department of botany in the University of Durham (Durham Division)The Head of the Department of Science, Lniversity of Durham, South Road, Durham (July 1). An F. W. Bennett lecturer in physics at University Colloge, Leicester-The Registrar, University College, Leicester (July 5). A graduate assistant master to teach mathematics, with elementary science as subsidiary subject, in the Halifax Junior Technical Sehool - The Principal, Municipal Technical College, Halifax. An assistant master for the teaching of painter's and decorator's work at the Huddersfield Technical College -The Director of Education, Education Offices, Peel Street, Huddersfield. A chief instructor in agricultural subjects at the Army Vocational Training Centre, Chisledon, Wiltshire-The Commandant, Army Vocational Training Centre, Chisledon, Wiltshire. 